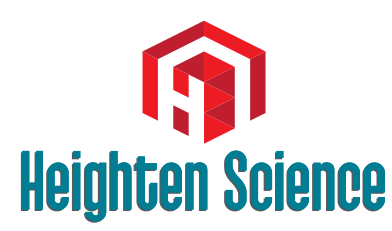

P U B L I C A T I O N S Corporation
Editorial

\section{CRISPR genome editing: A general}

\section{view}

\author{
Ram Mohan Ram Kumar* \\ Experimental Pathology, University Hospital Lausanne (CHUV), University of Lausanne, \\ Switzerland
}

*Address for Correspondence: Dr. Ram Mohan Ram Kumar, Experimental Pathology, University Hospital Lausanne (CHUV), University of Lausanne, Switzerland, Email:

ram.kumar@chuv.ch

Submitted: 13 June 2017

Approved: 21 June 2017

Published: 23 June 2017

Copyright: @ 2017 Kumar RMR. This is an open access article distributed under the Creative Commons Attribution License, which permits unrestricted use, distribution, and reproduction in any medium, provided the original work is properly cited

Check for updates target and determine particular DNA sequences in the genome circuit.
CRISPR technology has presented a path forward for genomic engineering and gene modification. The framework for the use of CRISPR technology to manipulate the human genome is of great interest and the form of its development and application has excited the researchers and biotech communities as the number of publications citing CRISPR gene targeting system has rose predominantly as indexed in PubMed. From a technical standpoint of view, most of us think that this would be relatively straightforward process, but technical feasibility is never the only consideration in doing experiments. Much of the discussion about CRISPR engineering has revolved mostly around its ability for treating disease or editing the genes of human embryos. In the real sense, what the biologists desire about CRISPR is its specificity: the ability to

Even though CRISPR has emerged as a revolution in genome editing within the scientific community, it has undergone a close scrutiny even within the non- scientific community. The thought of using CRISPR system for curing genetic diseases have gained support but a fewer does not support the use of this technology for editing the human germline cells which has the potential to transfer on their genetic information, has sparked a question about the role we are tempted to play in our own evolution. Interestingly, in an editorial that appeared on Science, it mentioned about a call for a moratorium on germline genome modification by discovers of CRISPR, scientists, ethicists and policymakers on using CRISPR in human subjects and cited a need for greater transparency in the CRISPR system. It also emphasised the need for optimised benchmarking and determination of off-target modifications made by the CRISPR system, the effects of which are largely unknown [1]. However, tremendous potential of CRISPR system for curing genetic diseases have been highlighted inspite of all the concerns.

CRISPR technology has been employed in human cells in vitro to modify genes responsible for hereditary diseases and this suggests a potential to treat numerous diseases. Xie et al. pioneered the use of this technology to treat disease-causing mutations in cells from beta-thalassemia patients [2]. Ebina et al., reported the use of this technology in eradicating HIV viral genomes from infected individuals by genome editing of HIV-1 virus [3]. Schwank et al., reported that CRISPR has the potential to repair cystic fibrosis condition in patients by editing the cystic fibrosis receptor locus [4]. Several research groups have already used the CRISPR technology to correct dystrophin mutation, which holds much promise treatment of Duchene Muscular Dystrophy (DMD) [5-9].

The coming years promise to be some of the most exciting times for genome editing. With much potential to treat genetic diseases it could usher in the new age of applied genetics but with high scrutiny. Quick and efficient editing of the genome without the 
off targets is the need of the hour giving a realistic possibility to cure the diseases. For the scientists using this technology and the lawmakers calling for open minded discussions of its serious ethical issues, and the millions of patients who could benefit from it, the coming years will have tremendous advances for CRISPR technology.

\section{REFERENCES}

1. Barrangou R. RNA events. Cas9 targeting and the CRISPR revolution. Science. 2014; 344: 707-708. Ref.: https://goo.gl/PDBhc1

2. Xie F, Ye L, Chang JC, Beyer Al, Wang J, et al. Seamless gene correction of $\beta$-thalassemia mutations in patient-specific iPSCs using CRISPR/Cas9 and piggyBac. Genome Res. 2014; 24: 1526-1533. Ref.: https://goo.gl/4JWJM4

3. Ebina $\mathrm{H}$, Misawa $\mathrm{N}$, Kanemura $\mathrm{Y}$, Koyanagi $\mathrm{Y}$. Harnessing the CRISPR/Cas9 system to disrupt latent HIV-1 provirus. Sci Rep. 2013; 3: 2510. Ref.:https://goo.gl/BFzgBn

4. Schwank G, Koo BK, Sasselli V, Dekkers JF, Heo I, et al. Functional repair of CFTR by CRISPR/Cas9 in intestinal stem cell organoids of cystic fibrosis patients. Cell Stem Cell. 2013; 13: 653-658. Ref.: https://goo.gl/82stVs

5. Li HL, Fujimoto N, Sasakawa N, Shirai S, Ohkame T, et al. Precise correction of the dystrophin gene in duchenne muscular dystrophy patient induced pluripotent stem cells by TALEN and CRISPR-Cas9. Stem Cell Reports. 2015; 4:143-54. Ref.: https://goo.gl/zHQsA6

6. Long C, Amoasii L, Mireault AA, McAnally JR, Li H, et al. Postnatal genome editing partially restores dystrophin expression in a mouse model of muscular dystrophy. Science. 2016; 351: 400-403. Ref.: https://goo.gl/e9FdEx

7. Nelson $\mathrm{CE}$, Hakim $\mathrm{CH}$, Ousterout DG, Thakore PI, Moreb EA, et al. In vivo genome editing improves muscle function in a mouse model of Duchenne muscular dystrophy. Science. 2015; 351: 403-407. Ref.: https://goo.gl/2boVPL

8. Tabebordbar M, Zhu K, Cheng JK, Chew WL, Widrick JJ, et al. In vivo gene editing in dystrophic mouse muscle and muscle stem cells. Science. 2015; 351: 407-411. Ref.: https://goo.gl/pm4wZ5

9. lyombe-Engembe JP, Ouellet DL, Barbeau X, Rousseau J, Chapdelaine P, et al. Efficient Restoration of the Dystrophin Gene Reading Frame and Protein Structure in DMD Myoblasts Using the CinDel Method. Mol Ther Nucleic Acids. 2016; Ref.: https://goo.gl/mvNd4b 